\title{
The effects of Tynnanthus fasciculatus (Bignoniaceae) infusion on testicular parenchyma of adult Wistar rats
} \author{
and Luciana C. Oliveira ${ }^{2}$ \\ ${ }^{1}$ Course of Biological Sciences, Federal University of Goiás, Campus Jataí, Goiás, Brazil \\ 2 Department of General Biology, Federal University of Viçosa, Minas Gerais, Brazil \\ 3 Department of Veterinary Science, Federal University of Viçosa, Minas Gerais, Brazil \\ ${ }^{4}$ Department of Anatomy, Cell Biology and Physiology, Unicamp, SP, Brazil
}

Fabiana C. S. A. Melo ${ }^{*}$, Sérgio L. P. Matta², Tarcízio A. R. Paula ${ }^{3}$, Marcos L. M. Gomes ${ }^{4}$

\begin{abstract}
Traditional medicine provides strong guidance for scientific experiments involving plant products used by the Brazilian people. The species "cipó-cravo" (Tynnanthus fasciculatus) is a plant commonly used either to combat indigestion and stomachaches, or as a general stimulant and aphrodisiac. In this study, the effects of "cipó-cravo" infusion were investigated within the testicular parenchyma of adult Wistar rats. Rats were divided into 3 groups: a control (distilled water) and two treated groups, which received the plant infusion (100 and $200 \mathrm{mg} /$ animal/day). The $200 \mathrm{mg}$ dose promoted a significant increase of the testicular parenchyma weight and of the volume and total length of the seminiferous tubules, as well as in total daily sperm production and sperm production per gram of testis.
\end{abstract}

Key terms: germ cell, Sertoli cell, sperm production, spermatogenesis.

\section{INTRODUCTION}

The use of medicinal plants and phytotherapy is expanding throughout the world, which establishes a promising pharmaceutical market. Surveys in different countries have shown that the use of medicinal plants is becoming increasingly popular in developed countries (Gullo and Pereira, 2001).

So-called stimulant and/or aphrodisiac plants are prominent in popular medicine, which is of great interest in the scientific community. Studies are being made on an ongoing basis and new findings have led to the development of drugs to be used against sexual dysfunctions, especially those related to males. The indiscriminate use of plants with aphrodisiac purposes is extremely dangerous given the lack of conclusive information about their mechanisms of action, and particularly their effects on the spermatogenic process.

The species known as "cipó-cravo" (Tynnanthus fasciculatus, Miers - Bignoniaceae), is popularly used as a powerful stimulant and aphrodisiac. It is also used to combat indigestion and stomachache. Lainetti and Brito (1979) first cited this plant for the treatment of diarrhea and control of worms, and Amorim et al. (1991) found anti-helminth action, significantly reducing the number of Oxyuridae in mice. Carvalho et al. (2007), using aqueous, ethanolic and dichloromethane extractions, identified the phytochemical constituents of $T$. fasciculatus, characterizing them as reducing sugars, phenolic compounds, tannins, flavonoids, cardiotonic heterosides, saponins, triterpenes and steroids.

The importance of $T$. fasciculatus in traditional medicine was the main reason to choose it as the theme of chemical, pharmacological and clinical trials for further investigation. Therefore, the aim of this study was to evaluate the effects of "cipó-cravo" (T. fasciculatus) infusion on the tubular compartment of adult Wistar rat testes.

\section{MATERIAL AND METHODS}

Plant samples

Bark of T. fasciculatus was collected in January 2006 from the Department of Forest Engineering located in the Federal University of Viçosa (UFV), Minas Gerais, Brazil. The material was identified by comparison with a voucher specimen deposited in the university herbarium ( $N^{\circ}$ 30074). The plant material was dried at $37^{\circ} \mathrm{C}$, passed through a grinding mill and the resulting material was collected, stored in a dry and well closed glass container at room temperature. All the doses used during this work were based on ethnobotanical data.

Experimental animals

The animals were housed and handled in accordance with the Manual on Care and Use of Laboratory Animals National Research Council, and in accordance with the Ethical Principles for the Use of Laboratory Animals recommended by COBEA/SBCAL - Science Society of Laboratory Animals. Thirty male Wistar rats (Rattus norvergicus) at reproductive age (120 days) were purchased from the Center for Biological Sciences and Health (CCBS) of the Federal University of Viçosa (UFV). They were weighed and placed into individual cages, separated in three experimental groups: a control group $(n=10)$ that received distilled water, and two treated ones that received the infusion of "cipó-cravo" at doses of 100 (CC100; n=10) or 200 $\mathrm{mg} /$ animal/day (CC200, $\mathrm{n}=10)$, respectively. Solid diet was provided ad libitum. The animals were kept under controlled temperature $\left(24.7 \pm 1.0{ }^{\circ} \mathrm{C}\right)$ and photoperiod $(12-12 \mathrm{~h}$ light/ dark) for 54 consecutive days. 
Harvesting and processing organs

The method of whole body perfusion, modified from Sprando (1990), was used for better tissue preservation. The rats were anesthetized and weighed, and then each animal was perfused for 15 minutes using saline followed by Karnovsky fixative (4\% paraformaldehyde: $4 \%$ glutaraldehyde in phosphate buffer $0.1 \mathrm{molL}^{-1}, \mathrm{pH}$ 7.4). After perfusion, the testicles were removed, weighed and put into new Karnovsky fixative for 24 hours. The testes used for the morphometrical analysis were dehydrated in ethanol and embedded in 2-hydroxyethyl methacrylate (Historesin ${ }^{\circledR}$, Leica). Two-micrometer-thick sections stained with toluidin blue-sodium borate $1 \%$ were used for microscopy and morphometry. Stained sections were viewed under an Olympus AX70 microscope (Olympus, Tokyo, Japan). The opposite testis was dissected in order to separate the tunica albuginea weight and calculate its proportion within the testis.

\section{Morphometrical and stereological studies}

The gonadal weight (GW) and seminiferous tubules weight (STW) were calculated in order to obtain the gonadosomatic and tubulesomatic indexes, respectively. To this purpose, these values were divided by the respective body weight (BW) as follows: GW/BW $\times 100$ and STW/BW x 100, respectively.

The volumetric proportions of tubular and interstitial compartments were estimated by projecting a $75 \times 75$ point orthogonal grid over digital images (10X magnification), giving a total of 2100 points per animal (Fig. 1A). The images were taken using a light microscope (Olympus AX-70) coupled to a U-Photo system and were analyzed using the software Image Pro Plus (v 4.0) for Windows. The volume $(\mathrm{mL})$ of each testicular component was estimated considering the percentage occupied by both seminiferous tubules and interstitium, times the testicular parenchyma volume. The parenchyma volume was obtained subtracting the albuginea weight from the testis weight. Since the testes density, in mammals, is situated at about 1 (Courot et al, 1970, Paula et al., 2002), the testis weight was considered equal to its volume.

The average diameter of seminiferous tubules was obtained from 20 random circular cross-sections of each animal. The seminiferous epithelium height was measured using the same sections in which the tubule diameter was obtained. To do so, epithelium height was considered as being the space between the tunica propria and the luminal edge. Two diametrically opposed readings were taken with a digital ruler on each cross section, using their mean value (Fig. 1B). All morphometrical analyses listed above were performed using digital images (100X magnification) with the software Image Pro Plus, v.6.0.

The total length (TL) of the seminiferous tubules, in meters, was estimated dividing the total volume occupied by the seminiferous tubules (STV) by their mean tubular diameter $\left(\mathrm{pR}^{2}, \mathrm{R}=\right.$ tubular diameter /2) (Ortavant et al., 1977, Curtis and Amann, 1981). To calculate the tubular length per gram of testis, the TL was divided by the testicular weight.

The germ cell population that constitutes the seminiferous epithelium in Stage 1 was estimated based on counting each cell nucleus within the cross sectioned tubule, including Sertoli cells (Swierstra, 1968, Courot et al., 1970, Ortavant et al., 1977, Curtis and Amann, 1981, Amann and Schanbacher, 1983). The following cell-types were quantified in 10 seminiferous tubule cross sections: type-A spermatogonia (SPTGA), primary spermatocytes at preleptotene/leptotene (SPT Pl/L) and pachytene (SPT P), round spermatids (RSPD) and Sertoli cells (S) (Fig. 1C). The mean nuclei and nucleoli diameters, the latter for Sertoli cells, were obtained by measuring 30 nuclei of each cell cited above. The measurements were performed on digital images using the software Image Pro Plus (v. 6.0). Due to size variations, the count of the different cell types was corrected by Abercrombie's formula (1946), further modified by Amann \& Almquist (1962). Based on the corrected values, it was possible to quantify the following coefficients: spermatogonial mitosis (SPT Pl/L/SPTGA), meiotic yield (RSPD/SPT P), spermatogenic yield (RSPD/SPTGA) and Sertoli cell index ((SPTGA + SPTC Pl/L + SPTC P + RSPD)/ S).

Daily sperm production (DSP) was calculated according to Amann and Almquist (1961) and Amann (1970). Each
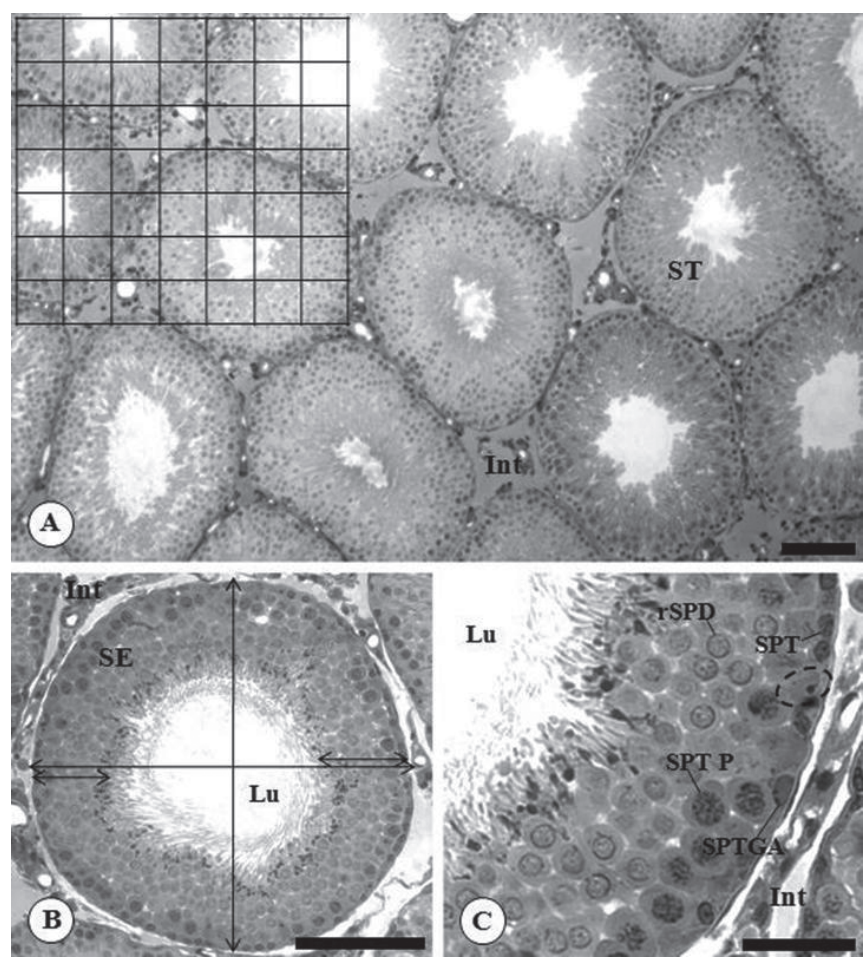

Figure 1: Histology of a normal Wistar rat testis. A. Wide view of the testicular parenchyma. Left corner: model of the square grid used to calculate the volumetric proportions of testicular components. B. Seminiferous tubule cross section showing how the tubular diameter (large arrows) and epithelium height (small arrows) were measured. The average values were considered in each case. C. Detail of the seminiferous epithelium on Stage 1, showing all different germ and somatic cell types. ST: seminiferous tubule; Int: interstitium; SE: seminiferous epithelium; Lu: lumen; rSPD: round spermatid; SPT: spermatocyte - pre leptotene; SPT P: spermatocyte pachytene; SPTGA: type A spermatogonia; dashed circle: Sertoli cell nucleus. Bars: $A$ and $B=100 \mu \mathrm{m} ; C=50 \mu \mathrm{m}$. 
seminiferous cycle lasts 12.8 days in Wistar rats (Van Haaster and De Rooij, 1993), which is constant for this species. In order to obtain the daily sperm production per gram of testis, daily sperm production was divided by the total weight of both testicles.

\section{Statistical analysis}

Data was expressed as the mean \pm standard error. The differences between groups were analyzed using Duncan's method. A 95\% significance level was used (alpha $=0.05)$.

\section{RESULTS}

All biometric data are shown in Table 1. Testes weight (TW) and testicular parenchyma weight (TPW) increased 8.6 and $8.7 \%(\mathrm{p}<0.05)$, respectively, in the animals that received the higher extract dose. The epididymis and the seminal vesicles did not show any significant alterations.

The gonadosomatic index (GSI) did not show significant differences among groups, while animals that received the higher doses of the plant extract showed a $10.2 \%$ increase of the tubulesomatic index (TSI), when compared to the CC100 group (Table 1). However, neither of the two groups showed statistical differences with the control animals.

The seminiferous tubule volumetric proportion decreased $3.45 \%$ in the CC100 group, while the interstitium proportion increased $18.22 \%$ (Table 2). There was a $10.3 \%$ increase of the volume occupied by the seminiferous tubules in the animals that received the higher extract dose (CC200) (Table 2).

Although there were no alterations in the tubular diameter during this study, the epithelium height in CC200 was lower $(7.34 \%)$ than that observed in the CC100 group, but no alterations were found in regard to the control group (Table 2). The total length (TL) of the seminiferous tubules in CC200 animals showed a $13.2 \%$ increase compared to the control, while the TL per gram of testis had a $15.29 \%$ increase compared to CC100 animals (Table 2). However, neither of the two groups showed statistical differences to the control animals.

The corrected number of germ cells per section of seminiferous tubule at Stage I and the number of round spermatids per testis are shown in Table 3. The number of primary spermatocytes in pre-leptotene/leptotene increased $10.05 \%$ in group CC200, while the number of round spermatids per testis increased $22.56 \%$, compared to the control $(\mathrm{p}<0.05)$. The other cell line populations remained similar among the groups (Table 3 ).

The ratios of cell numbers to assess the spermatogenic process, the Sertoli cell number and the daily spermatic production (DSP) are found in Table 4. The calculated indexes showed no significant variation among treatments, as also occurred for Sertoli cell number per testis and per gram of testis. However, daily sperm production (DSP) increased $22.48 \%$ in the CC200 group $(\mathrm{p}<0.05)$, while DSP per gram of testis increased $14.3 \%$ in the same group $(\mathrm{p}<0.05)$.

Table 1

Biometric characteristics of adult male Wistar rats, after treatment with Tynnanthus fasciculatus aqueous infusion (mean \pm SD; $\mathrm{n}=10$ ).

\begin{tabular}{lccc}
\hline Parameters & Control & CC 100 & CC 200 \\
\hline BW (g) & $480.00 \pm 31.62^{\mathrm{a}}$ & $479.00 \pm 22.83^{\mathrm{a}}$ & $490.00 \pm 19.44^{\mathrm{a}}$ \\
TW (g) & $3.04 \pm 0.29^{\mathrm{b}}$ & $3.06 \pm 0.18^{\mathrm{b}}$ & $3.3 \pm 0.24^{\mathrm{a}}$ \\
TPW (g) & $2.89 \pm 0.27^{\mathrm{b}}$ & $2.91 \pm 0.18^{\mathrm{b}}$ & $3.14 \pm 0.22^{\mathrm{a}}$ \\
GSI (\%) & $0.64 \pm 0.07^{\mathrm{a}}$ & $0.64- \pm 0.04^{\mathrm{a}}$ & $0.67 \pm 0.05^{\mathrm{a}}$ \\
TSI (\%) & $0.50 \pm 0.05^{\mathrm{ab}}$ & $0.49 \pm 0.03^{\mathrm{b}}$ & $0.54 \pm 0.04^{\mathrm{a}}$ \\
\hline
\end{tabular}

Means with the same letter (P>0.05); Duncan test. Control: distilled water, CC100: T. fasciculatus 100 mg/animal/day; CC200: T. fasciculatus 200 mg/animal/ day. $\mathrm{BW}=$ body weight; $\mathrm{TW}=$ testes weight; TPW = testicular parenchyma weight; $\mathrm{GSI}=$ gonadosomatic index and $\mathrm{TSI}=$ tubulesomatic index.

Table 2

Volumetric proportion (\%) and volume $(\mathrm{mL})$ of the testicular compartments, tubular diameter (TD), epithelium height (EH), total length (TL) and total length per gram of testis (TL/gT) of adult male Wistar rats, treated with Tynnanthus fasciculatus (mean \pm SD; $\mathrm{n}=10$ ).

\begin{tabular}{lccc}
\hline Parameters & Control & CC 100 & CC 200 \\
\hline Seminiferous Tubule $(\%)$ & $84.08 \pm 1.06^{\mathrm{b}}$ & $81.18 \pm 2.97^{\mathrm{a}}$ & $85.27 \pm 3.76^{\mathrm{b}}$ \\
Interstitium $(\%)$ & $15.92 \pm 1.06^{\mathrm{b}}$ & $18.82 \pm 2.97^{\mathrm{a}}$ & $14.73 \pm 3.76^{\mathrm{b}}$ \\
Seminiferous Tubule $(\mathrm{mL})$ & $2.43 \pm 0.23^{\mathrm{b}}$ & $2.36 \pm 0.16^{\mathrm{b}}$ & $2.68 \pm 0.20^{\mathrm{a}}$ \\
Interstitium $(\mathrm{mL})$ & $0.46 \pm 0.06^{\mathrm{a}}$ & $0.55 \pm 0.10^{\mathrm{a}}$ & $0.46 \pm 0.13^{\mathrm{a}}$ \\
$\mathrm{TD}(\mu \mathrm{m})$ & $301.37 \pm 20.00^{\mathrm{a}}$ & $309.77 \pm 16.46^{\mathrm{a}}$ & $296.46 \pm 20.01^{\mathrm{a}}$ \\
$\mathrm{EH}(\mu \mathrm{m})$ & $99.03 \pm 7.48^{\mathrm{ab}}$ & $101.57 \pm 7.59^{\mathrm{a}}$ & $94.11 \pm 6.94^{\mathrm{b}}$ \\
$\mathrm{TL}(\mathrm{m})$ & $34.56 \pm 5.74^{\mathrm{b}}$ & $31.64 \pm 4.20^{\mathrm{b}}$ & $39.12 \pm 4.47^{\mathrm{a}}$ \\
$\mathrm{TL} / \mathrm{gT}(\mathrm{m} / \mathrm{g})$ & $11.35 \pm 1.58^{\mathrm{ab}}$ & $10.34 \pm 1.17^{\mathrm{b}}$ & $11.92 \pm 1.67^{\mathrm{a}}$ \\
\hline
\end{tabular}


Table 3

Corrected cell population, by tubule cross section, at stage 1 of the seminiferous epithelium and the number of round spermatids per testis of adult Wistar rats treated with Tynnanthus fasciculatus infusion (mean $\pm S D, n=10$ ).

\begin{tabular}{lccc}
\hline Parameters & Control & CC 100 & CC 200 \\
\hline SPTGA & $1.29 \pm 0.35^{\mathrm{a}}$ & $1.19 \pm 0.28^{\mathrm{a}}$ & $1.14 \pm 0.30^{\mathrm{a}}$ \\
SPTI Pl/L & $17.61 \pm 1.91^{\mathrm{b}}$ & $18.93 \pm 1.84^{\mathrm{ab}}$ & $19.38 \pm 1.43^{\mathrm{a}}$ \\
SPTI P & $21.85 \pm 2.36^{\mathrm{a}}$ & $21.05 \pm 1.84^{\mathrm{a}}$ & $22.25 \pm 1.79^{\mathrm{a}}$ \\
RSPD & $64.01 \pm 5.53^{\mathrm{a}}$ & $65.70 \pm 7.19^{\mathrm{a}}$ & $69.97 \pm 6.52^{\mathrm{a}}$ \\
RSPD /T $\left(\times 10^{7}\right)$ & $55.40 \pm 11.50^{\mathrm{b}}$ & $51.80 \pm 8.10^{\mathrm{b}}$ & $67.90 \pm 6.10^{\mathrm{a}}$ \\
\hline
\end{tabular}

Means with the same letter (P>0.05); Duncan test. Control: distilled water, CC100: T. fasciculatus 100 mg/animal/day; CC200: T. fasciculatus 200 mg/animal/ day. SPTGA = type A spermatogonia; SPTI PI/L = primary spermatocyte (pre-leptotene/leptotene); SPTI P = primary spermatocyte (pachytene); RSPD = round spermatid, RSPD/T = round spermatid per testis.

Table 4

Ratios between cell numbers, Sertoli cell numbers and daily spermatic production in adult Wistar rats treated with Tynnanthus fasciculatus infusion (mean $\pm \mathrm{SD} ; \mathrm{n}=10$ ).

\begin{tabular}{lccc}
\hline Parameters & Control & CC 100 & CC 200 \\
\hline Spermatogenic Index (mitosis) & $14.45 \pm 4.05^{\mathrm{a}}$ & $16.81 \pm 4.56^{\mathrm{a}}$ & $17.99 \pm 4.56^{\mathrm{a}}$ \\
Meiotic Index & $2.95 \pm 0.31^{\mathrm{a}}$ & $3.12 \pm 0.16^{\mathrm{a}}$ & $3.15 \pm 0.24^{\mathrm{a}}$ \\
Spermatogenic Yield & $52.86 \pm 15.03^{\mathrm{a}}$ & $58.4 \pm 16.34^{\mathrm{a}}$ & $65.11 \pm 17.63^{\mathrm{a}}$ \\
Sertoli Support Capacity & $17.91 \pm 2.29^{\mathrm{a}}$ & $47.36 \pm 2.31^{\mathrm{a}}$ & $19.19 \pm 2.16^{\mathrm{a}}$ \\
S/testis $\left(\times 10^{6}\right)$ & $51.37 \pm 11.87^{\mathrm{a}}$ & $57.69 \pm 7.84^{\mathrm{a}}$ & $32.32 \pm 6.38^{\mathrm{a}}$ \\
S/g testis $\left(\times 10^{6}\right)$ & $33.64 \pm 6.65^{\mathrm{a}}$ & $81.02 \pm 12.70^{\mathrm{b}}$ & $35.22 \pm 5.98^{\mathrm{a}}$ \\
DSP $\left(\mathrm{x} 10^{6}\right)$ & $86.71 \pm 18.00^{\mathrm{b}}$ & $26.52 \pm 4.07^{\mathrm{b}}$ & $106.21 \pm 9.52^{\mathrm{a}}$ \\
DSP/g testis $\left(\times 10^{6}\right)$ & $28.39 \pm 4.71^{\mathrm{b}}$ & & $32.45 \pm 4.61^{\mathrm{a}}$ \\
\hline
\end{tabular}

Means with the same letter (P>0.05); Duncan test. Control: distilled water, CC100: T. fasciculatus 100 mg/animal/day; CC200: T. fasciculatus 200 mg/animal/day. S: Sertoli cells, DSP: daily spermatic production.

\section{DISCUSSION}

There was a significant increase in testicular mass and parenchyma weight after treatment with the higher concentration of T. fasciculatus infusion $(200 \mathrm{mg} / \mathrm{kg})$, mainly due to the alterations of the productive portion (gametogenic and androgenic), since the albuginea weight showed no variations. In those animals, the increase of seminiferous tubule volume indicates an increase in spermatic production. Rats treated with Cynomorium coccineum (Abdel-Magied et al., 2001) and Lepidium meyenii (Gonzales et al., 2001) extracts also had a considerable increase of mean testicular weight due to the increase in seminiferous tubule size and the proliferation of germ cells, characterizing higher spermatogenic efficiency. Testes weight and size can be used as quantitative indicators of the spermatic production (França \& Russell, 1998), since the main testicular component is the seminiferous tubule.

Although an increase in testicular weight was found for group CC200, the gonadosomatic index (GSI), which represents the percentage of body mass that corresponds to the testis, showed no significant alterations. This is probably due to the small increase of body weight in the animals of this group, which was not significant.

The tubulesomatic index (TSI) is a parameter used to quantify the seminiferous tubules in relation to body mass
(Paula et al., 2002). The TSI was higher in CC200 animals than in group CC100, although this value remained unaltered in comparison to the control group, representing higher commitment in spermatic production in the animals that received the more concentrated extract.

According to França \& Russell (1998) there is a positive relation between tubular diameter and the spermatogenic activity. The treatment with both concentrations of $T$. fasciculatus did not affect the tubular diameter; however, the height of the seminiferous epithelium presented reduction in group CC200 compared with the group CC100.Both results did not differ significantly from the control group, suggesting that no major damages were caused, specially regarding spermatogenesis. Similar results were achieved by França et al. (2000) working with cimetidine, a substance used in the treatment of duodenal and gastric ulcers, which is toxic to the testes, causing atrophy of these organs. Although no alterations were noticed in seminiferous tubule diameter of rats treated with cimetidine, there was a reduction of the seminiferous epithelium height, without severely compromising the spermatogenic process.

The total length of the seminiferous tubules is related to three structural parameters: testicular size, tubular diameter and seminiferous tubule volume. Therefore, the increase of the testicular weight and the seminiferous tubule volume in animals that received $T$. fasciculatus in the concentration to 
$200 \mathrm{mg}$, reflected a significant increase of the total length of the seminiferous tubules, what can lead to an increase in spermatic production.

The total length of seminiferous tubules per gram of testis ranged from 10 to 15 meters, which is considered normal for the majority of mammals (França and Russell, 1998). The group that received $200 \mathrm{mg}$ presented a higher seminiferous tubule length per gram of testis then the animals that received $100 \mathrm{mg}$.

The quantification of different cell lineages per crosssection of seminiferous tubule in various stages of the spermatogenic cycle enables a deep functional analysis of the testicular parenchyma and also permits an estimate of sperm production, revealing spermatogenesis kinetics (Clermont, 1972; França, 1991).

Male rats, treated with Barleria prionitis (Acanthaceae) extract, resulted in a reduced population of several types of spermatogenic cells, affecting their reproductive efficiency by modification of spermatogenesis (Verma et al., 2005). The treatment with the highest dose of $T$. fasciculatus infusion $(200 \mathrm{mg} / \mathrm{kg} /$ day) caused an increase in the number of primary spermatocytes at pre-leptotene/leptotene. The primary spermatocytes are formed after the mitotic divisions of spermatogonia. Thus, the increase in the primary spermatocyte number could be related to diminished loss of the proliferative or spermatogonial cell phases. In this case, there would be less degeneration than normally occurs in the cellular conversion from spermatogonia to primary spermatocytes in pre-leptotene. This increase resulted in a significant increase in the number of round spermatids per testis in animals treated with the $200 \mathrm{mg}$ dose.

The ratio between the different types of germ cells is a very reliable way to analyze the efficiency of the spermatogenic process, allowing comparisons among different species (Paula et al., 2002). In the present study, the animals treated with the higher concentration of $T$. fasciculatus infusion $(200 \mathrm{mg} / \mathrm{kg} /$ day) showed the highest ratio of spermatogenic cell numbers. These data might be associated with the reduction of germ cell loss by the intake of the plant infusion, in agreement with previous studies of this infusion that showed an antioxidant activity in vitro, this suggests that this plant may have components which inhibit the action of free radicals produced during metabolic processes (Santi and Mattei, 2003).

The interactions between Sertoli cells and germ cells are crucial for maintaining normal sperm production. The population of Sertoli cells, as well as its total support capacity (number of germ cells held by a Sertoli cell), remained constant in all experimental groups, which is in accordance with França and Russel (1998), who believed that Sertoli cells no longer divide after the perinatal period in most animals.

The efficiency of spermatogenesis is measured by daily sperm production (DSP) and DSP per gram of testis. In rats, which show high spermatogenic efficiency, the DSP per gram of testis is 20 to $24 \times 10^{6}$ spermatids (Daduone and Demuolin, 1993; Johnson, 1995). The results of DSP per gram of testis were within the normal range for the species. However, the animals treated with the highest dose of $T$. fasciculatus infusion (200mg) showed significantly higher values of total DSP and DSP per gram of testis in relation to other experimental groups, indicating an increase in sperm production, as observed for Butea superba (Manosroi et al., 2006) and Satureja khuzestanica (Haeri et al., 2006) treatments.

The DSP is related to both the number of round spermatids and the total length of seminiferous tubules. The increase of the total length of seminiferous tubules and the increase of the number of round spermatids per testis in animals treated with T. fasciculatus infusion (CC200) confirmed the increase in the final amount of sperm produced.

Therefore, the presented data suggests that the treatment with the highest dose of T. fasciculatus infusion promoted an increase in testicular weight, in the volume and total length of the seminiferous tubules and in total daily sperm production, leading to a higher efficiency of the spermatogenic process. In addition, there were no visible alterations in within the parenchyma that could compromise the spermatogenesis as a whole.

\section{ACKNOWLEDGEMENTS}

The authors wish to thank FAPEMIG (Fundação de Amparo à Pesquisa no Estado de Minas Gerais) for the concession of the scholarship and FAFILE/UEMG (Fundação Fafile de Carangola) for the support and permission for the academic activities.

\section{REFERENCES}

ABDEL-MAGIED EM, ABDEL-RAHMAN HA, HARRAZ FM (2001) The effect of aqueous extracts of Cynomorium coccineum and Withania somnifera on testicular development in immature Wistar rats. J Ethnopharmacology 75: 1-4.

AMANN RP (1970) Sperm production rates. In: JOHNSON AD, GOMES WR, VANDEMARK NL (eds) The testis. New York: Academic Press. pp: 433-482.

AMANN RP, ALMQUIST JO (1961) Reproductive capacity of dairy bulls I. Technique for direct measurement of gonadal and extra-gonadal sperm reserves. J Dairy Sci 44: 1537-1543.

AMANN RP, ALMQUIST JO (1962) Reproductive capacity of dairy bulls. VIII. Direct and indirect measurement of testicular sperm production. J Dairy Sci 45: 774-781.

AMANN RP, SCHANBACHER BD (1983) Physiology of male reproduction. J Anim Sci 57: 380-403.

AMORIM A, BORBA HR, AMANO LM (1991) Ação anti-helmíntica de plantas IV. Influência da casca do caule de cipó-cravo (Tynnanthus fasciculatus Miers; Bignoniaceae) na eliminação de Vampirolepis nana e de oxiurídeos em camundongos. Rev Bras Farm 72: 92-94.

CARVALHO CA, OLIVEIRA TG, MANFRÉ RVR, ANDRADE DC, MATTA SLP, SILVA MB, ROSA MB (2007) Estudo fitoquímico de Tynnanthus fasciculatus - Bignoniaceae. $47^{\circ}$ Congresso Brasileiro de Olericultura, Porto Seguro. Anais do Congresso Brasileiro de Olericultura, 25: 1-176.

CLERMONT Y (1972) Kinetics of spermatogenesis in mammals: seminiferous epithelium cycle and spermatogonial renewal. Physiol Rev 52: 198-236.

COUROT M, HOCHEREAU-DE-REVIERS MT, ORTAVANT R (1970) Spermatogenesis. In: JOHNSON AD, GOMES WR, VANDENMARK NL (eds) The testis. New York: Academic Press. pp: 339-432.

CURTIS SK, AMANN RP (1981) Testicular development and establishment of spermatogenesis in Holstein bulls. J Anim Sci 53: 1645-1657.

DADUONE JP, DEMUOLIN A (1993) Structure and functions of the testis. In: THIBAULT C, LEVASSEUR M, HUNTER RHF (eds) Reproduction in mammals and man. Paris: Ellipses. pp: 227-250.

FRANÇA LR (1991) Análise morfofuncional da espermatogênese de suínos adultos da raça Piau. Belo Horizonte: UFMG. 180p. (thesis)

FRANÇA LR, RUSSELL LD (1998) The testis of domestic mammals. In: MARTINEZ-GARCIA F, REGADERA J (eds) Male reproduction - a multidisciplinary overview. Madrid: Churchill Comunications. pp: 198-219. 
FRANCA LR, LEAL MC, CERRI-SASSO E, VASCONCELOS A DEBELJUK L, RUSSELL LD (2000) Cimetidine (Tagamet) is a reproductive toxicant in male rats affecting peritubular cells. Biol Reprod 63: 1403-1412.

GONZALES GF, CORDOVA A, GONZALES C, CHUNG A, VEGA K, VILLENA A (2001) Lepidium meyenii (Maca) improved semen parameters in adult men. Asian J Androl 3: 301-303.

GULLO C., PEREIRA C (2001) A cura no jardim. Isto É 1513: 72-78.

HAERI S, MINAIE B, AMIN G, NIKFAR S, KHORASANI R, ESMAILY H, SALEHNIA A, ABDOLLAHI M (2006) Effect of Satureja khuzestanica essential oil on male rat fertility. Fitoterapia 77: 495-499.

JOHNSON L (1995) Efficiency of spermatogenesis. Microscopy Research and Technique 32: 385-422.

LAINETTI R, BRITO NRS (1979) A cura pelas ervas e plantas medicinais brasileiras. Editora Tecnoprint Ltda, Rio de Janeiro.

MANOSROI A, SANPHET K, SAOWAKON S, ARITAJAT S, MANOSROI J (2006) Effects of Butea superb on reproductive systems of rats. Fitoterapia 77: 435-438.

ORTAVANT R, COUROT M, HOCHEREAU-DE-REVIERS MT (1977) Spermatogenesis in domestic mammals. In: COLE HH, CUPPS PT (eds) Reproduction in domestic animals. New York: Academic Press. pp: 203-227.
PAULA TAR, COSTA DS, MATTA SLP (2002) Avaliação histológica quantitativa do testículo de capivaras (Hydrochoerus hydrochaeris) adultas. Biosci J 18: 121-136.

SANTI D; MATTEI, R. (2003). Propriedade terapêutica do cipó-cravo. AGENCIA FAPESP. Available in: http://www.agencia.fapesp.br/ materia/1127/noticias/propriedade-terapeutica-do-cipo.htm. Accessed on January 20, 2008.

SPRANDO RL (1990) Perfusion of the rat testis through the heart using heparin. In: RUSSELL LD, ETTLIN RA, HIKIM APS, CLEGG ED (eds) Histological and Histopathological Evaluation of the Testis. Clearwater: Cache River Press. pp: 277-280.

SWIERSTRA EE (1968) Cytology and duration of the cycle of the seminiferous epithelium of the boar: duration of spermatozoa transit through the epididymis. Anat Rec 161: 171-186.

VAN HAASTER LH, DE ROOIJ DG (1993) Spermatogenesis is accelerated in the immature Djungarian and Chinese hamster and rat. Biol Reprod 49: 1229-1235.

VERMA PK, SHARMA A, JOSHI SC, GUPTA RS, DIXIT VP (2005) Effect of isolated fractions of Barleria prionitis root methanolic extract on reproductive function of male rats: preliminary study. Fitoterapia 76: $428-432$. 